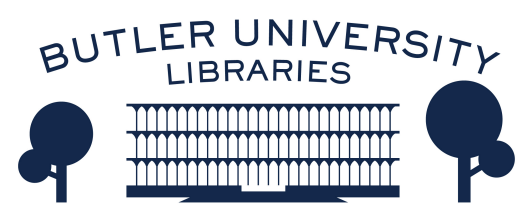

Journal of Hindu-Christian Studies

Volume 23

Article 22

January 2010

\title{
Book Review: "Beyond Boundaries: Hindu-Christian Relationship and Basic Christian Communities"
}

Chad M. Bauman

Follow this and additional works at: https://digitalcommons.butler.edu/jhcs

Part of the Religion Commons

\section{Recommended Citation}

Bauman, Chad M. (2010) "Book Review: "Beyond Boundaries: Hindu-Christian Relationship and Basic Christian Communities"," Journal of Hindu-Christian Studies: Vol. 23, Article 22.

Available at: https://doi.org/10.7825/2164-6279.1474

The Journal of Hindu-Christian Studies is a publication of the Society for Hindu-Christian Studies. The digital version is made available by Digital Commons @ Butler University. For questions about the Journal or the Society, please contact cbauman@butler.edu. For more information about Digital Commons @ Butler University, please contact digitalscholarship@butler.edu. 
Christianity appealed to people in the marginslow-castes, outcastes, and tribals.

Chandra Mallampalli's essay demonstrates the fact that Indian Christianity often tended to adapt itself to the caste system rather than trying to subvert it and critiques Frykenberg's bottomup approach to argue that colonial Raj deindigenizes the indigenized Catholic Church based on court cases pertaining to identity issues among South Indian Roman Catholics. Additionally, he candidly discusses both the methods, from below and above, and leaves the option for historians to employ either approach to tell the story of Indian Christianity, which would have different outcomes. On a different note, Geoffery Oddie contends that the missionaries' contact with Hindu pundits was a significant event in missionary endeavors, but he cautions that there were other factors that played a role in the missionary construction of Hindu religion, as well (pp. 180). Michael Bergunder's essay discusses the problematic issue of proselytism in the history of Christianity in India and states that people changed denominations when a particular denomination of Christianity did not keep up to its promise of providing material incentives. Additionally, change of church affiliation presupposes peršonal agency-a reason for proselytism in the Indian Christian context (pp. 195). Gunnel Cedarlöf's essay argues that, unlike the other Protestant churches, the European-based Evangelical Lutheran mission had a dual stand on the question of nationalism, partly because they had developed as church missions, built on national churches with a strong resonance of the north European nationalist movements (pp. 198). For this Lutheran mission the late-nineteenth and early twentieth century romantic and nationalistic idea of volk became central in their work and gave the idea of an indigenous Christian nation. As an outcome, the local Tamil Lutherans accepted the caste system as part of their folk character.

Judith Brown discusses how Jawaharlal Nehru, the first Prime Minister of independent India, understood the role of Christians in the new India who were under pressure. Because of Nehru's concern about a conception of nationalism that would preclude minority voices, including Christians, he found immensely challenging his promotion of a need for tolerance in a plural society of India, especially because those who controlled state power and public communications had visualized India as less tolerant and less plural than Nehru (pp. 234). John B. Carman's Christian interpretation of Ramanuja, the eleventh century Indian philosopher, sets a valuable paradigm for HinduChristian dialogue highlighting the challenges involved and the complexity of such theological engagement. Carman emphasizes three aspects beneficial for comparative theology: a Christian student of another religion must live in the awareness that theological incorporation of some aspects of Hindu beliefs and practices into Christian life involves an understanding of those elements different from that of the Hindu believer; a Christian scholar must appreciate viewpoints that at times seem similar and at times different; and Christian scholars must be cognizant of myriad Indian Christian perspectives (pp. 239). He concludes his essay with a list of items representing the complexity and challenging task of theological interpretation. The volume concludes with essays by Rosemary Seton and Martha Lynd Smalley that offer extremely useful surveys of archival information for those interested in conducting research in the history of Christianity in India.

George Pati

Valparaiso University

\section{Beyond Boundaries: Hindu-Christian Relationship and Basic Christian Communities. A. Maria David. Delhi: ISPCK, 2009, pp. $\mathrm{XV}+281$.}

BEYOND Boundaries is an analysis of "basic Christian communities" established in the diocese of Kottar, district of Kanyakumari (Tamil Nadu), and their potential for helping 
promote interreligious harmony in a region visited, in the $1980 \mathrm{~s}$, by several significant Hindu-Christian conflicts, at least one of them deadly. Basic Christian communities (BCCs), also known as basic ecclesial communities (and by several other names) are small, lay-led groups, organized since the 1960s within Catholic parishes around the world, to discuss and provide leadership on social, religious, and even liturgical issues and problems. They take inspiration, in their grass-roots origins, lay orientation, and participatory nature, from both Liberation Theology and Vatican II. In Kanyakumari the BCCs are called anbiam (from the Tamil, "community of love") in the singular, and anbiangal in the plural.

Anbiangal were first established in the district in 1979 by Fr. M. J. Edwin, who worked in the coastal village of Kodimunai. Control of village politics in Kodimunai was dominated by small but influential cliques, "who managed to maintain themselves always in power [such that] ordinary people were only supporters of these groups but had no access to...the decisionmaking process" (118). This lack of access was particularly prevalent in the case of women. To combat the control of these elites Edwin established seventeen communities of thirty families each that met once a week for prayer and informal education, to discuss religious issues and social problems, and to plan strategies for improving their lives and the lives of their neighbors. The result, David contends, was a significant and desirable de-centering of power, not only in the village, but in the diocese as well: "Thus anbiangal in the district of Kanyakumari were started, not as part of the basic Christian communities movement network at the global level or as part of a planned diocesan programme from above[, but] as a response to the situation in a particular village and through the initiative of the pastor and the openness and co-operation shown by the people, especially the women, the poor and the marginalized ones in the village" (119).

The anbiangal were so successful, particularly in giving voice to those who would not have spoken up in larger assemblies, that they began to spread outward from Kodimunai. At first the diocesan church hierarchy resisted the growing influence of the anbiangal. But eventually, after their advantages were discerned by diocesan officials, Edwin was given responsibility for nurturing existing anbiangal in the diocese and expanding them to areas where they had not yet been established. Sociologists familiar with Max Weber's work might wonder whether their charisma was tamed by this institutionalization, and in fact some taming does appear to have occurred. At the same time, however, the anbiangal appear to have influenced the orientation of the church itself in significant and-David suggests-positive ways.

In an early chapter of the book David provides an overview of Hindu-Christian relations in the region, from the earliest missionary period until recent times. A great deal of the chapter focuses on two conflicts which occurred in the early 1980s: One a set of riots in and around Mandaikadu which resulted in the police firing (fatally) on a Christian crowd, and the second a property dispute in Manali-Kuzhivilai that was resolved relatively amicably by the courts. In fact, though intended merely to provide contextual detail for the rest of the study, this chapter is in many ways the book's best. It is well-researched, detailed, nuanced, and fascinating, and in dealing with recent Hindu-Christian conflicts David is careful to acknowledge that fault lies with both communities, not just with Hindus.

The focus of the book is not on these conflicts, however, but on the current relations between Hindus and Christians, which remain strained, and on the question of whether the anbiangal could be used by diocesan leaders to promote interreligious cooperation and understanding. David's contention is that they could. The anbiangal already display a considerable degree of tolerance of Hinduism and engagement with local Hindus. For example, Hindus are occasionally members of the anbiangal, they occasionally extend their charity to impecunious Hindus (not just to Christians). In addition, anbiangal members seem to participate relatively regularly in Hindu festivals and rituals, even those taking place within temples. 
Like all books, Beyond Boundaries is imperfect. Its origins as a doctoral thesis (at the University of Madras's well-respected Department of Christian Studies) are overly evident at times, and the text as a whole is too lightly edited. Moreover, the book assumes an audience already somewhat familiar with BCCs (I, unfortunately, was not); no formal definition of the term is given for over a hundred pages. The book also reads, in certain passages, as if it is part of an internal Catholic conversationDavid is a member of the Carmelite Order and a native of the district-and at times the BCCs under investigation seem to be judged by how well they conform to certain assumed but largely unstated ideals.

More problematic, however, is the structure of the main thesis. The author argues that the anbiangal display a significant and increasing degree of tolerance for and engagement with Hindus and Hinduism (one of the assumed ideals), and should therefore be more intentionally and systematically used by the church hierarchy to promote interreligious harmony. That may in fact be true, but the evidence given to support the assertion comes entirely from an analysis of the BCCs. No comparative investigation of attitudes among Catholics more generally was done (or referenced) to demonstrate whether the tolerance and engagement displayed by the anbiangal was unique to them or merely a reflection of changing norms and perspectives in the Catholic Church more generally (or at least among lay Indian Catholics). In fact, at various points the testimonies cited by the author suggest that the most significant factor in the emergence of more tolerant attitudes about Hinduism was not the formation of the BCCs, but rather the declining influence of missionaries and of an older generation of priests who tended to disparage Hinduism and discourage Christian participation in Hindu festivals and rituals. That said, it is not my intention to contradict the author's findings - he may, and even quite likely is, correct—but rather to indicate that the argument could have been made more persuasively.

Despite these minor issues, Beyond Boundaries is a worthwhile, thoughtful, and provocative read, and would be particularly appealing to scholars or students of Indian Catholicism/Christianity, those who conduct research on Hindu-Christian conflict, and Catholic leaders interested in new ways of "being Church."

Chad M. Bauman

Butler University

\section{Hermeneutics and Hindu Thought: Toward a Fusion of Horizons. Edited by Rita Sherma and Arvind Sharma. N.p.: Springer, 2008, 249 pp.}

THIS collection of eleven essays plus a set of responses by Sharma was initially inspired by a 2003 panel on Hindu philosophy and hermeneutics at the American Academy of Religion Annual Meeting. Some of its individual pieces are critical, historical, or analytical in nature, and others are constructive, but all address the relative absence of a truly dialogic encounter between the philosophical traditions of Hinduism and those of the West. As Rita Sherma's introduction to the volume puts it, these essays examine
1) The challenges and possibilities inherent in the application of Western hermeneutics to the study of Hindu traditions; 2) Critiques of certain heuristics used to "understand" Hindu traditions in the past; 3) The elicitation of new hermeneutical paradigms from the Hindu texts and traditions, in order to develop cross-cultural or dialogical hermeneutics (1).

Sherma's fine introductory essay traces the history of hermeneutics in the West from Schleiermacher through Dilthey, Heidegger, 